\title{
The Impact of Human Capital and Social Capital on Employee Performance: A Study of Employees in Small Scale Industry Enterprises in Western Province of Sri Lanaka
}

\author{
K. A. C. N. Perera ${ }^{1}$ and W. A. S. Weerakkody ${ }^{2 *}$ \\ ${ }^{1,2}$ Department of Human Resource Management, Faculty of Commerce and \\ Management Studies, University of Kelaniya, Sri Lanka \\ ${ }^{1}$ chamalinisansala2@gmail.com, ${ }^{2}$ was@kln.ac.lk \\ *https://orcid.org/0000-0003-3710-8528
}

\begin{abstract}
The human capital and Social Capital are most focus areas for the further research study. Previous literature was identified the importance of these human capital and social capital, even though there is less sufficient evidence regarding these areas. It is hard to find research which is done in Sri Lankan context that investigate on the relationship between human capital and social capital on employee performance in small scale industrial enterprises in Sri Lanka. Therefore the main objective of the study was to identify the whether there are significant effect from human capital and social capital to employee performance. The research framework contains of two Independent variable (Human Capital, Social Capital) dependent variable (employee performance).Therefore the purpose of the study was hypotheses testing. The study was cross sectional. It means collected only at a single point in time due to time horizon. Measures of this study retained adequate validity and reliability. Sample for this study was employees in small scale industrial enterprises in western province, Sri Lanka. The structured questionnaire, which consists of 65 statement with five point Likert scale used to gather data and sample consists of 316 employees in small scale enterprises in western province. Therefore unit of analysis was individual level. The data analysis contained within univariate and multivariate analysis. The research discovered that there were positive strong impact of human capital on employee performance. And also there were positive moderate impact of social capital on employee performance in small scale industrial enterprises in Sri Lanka.
\end{abstract}

Keywords: Human Capital, Social Capital, Employee Performance

\section{Introduction}

Human capital is a quality of a person that include person knowledge, skill, and qualification, acquired through education, training and experience (Becker 1993). During the last years, Most of the past research had been conduct research on relationship between human capital and job performance, while few research have use this concept as mediate variable (Becker,
1964; Jensen, 1988; Harris \& McMahan, 2008; Hawkins \& Dulewicz, 2007; Ng et al., 2005; Pil \& Leana, 2009; Wright, Smart, McMahan, 1995; sujchaphong, 2013). Social capital included the context, stock of relationships, interpersonal trust and norms, behavior, interconnection between individuals which are guarantee about condition for the development of organization (Anklam, 2002; Felício, Couto, \& 
Caiado, 2014). According to Burt (1997) managers with more social capital be likely to have quick promotions and better bonuses. Harris and McMahan (2008) found that NCAA basketball teams containing of players with better knowledge and skills, that positively impact better team performance. Most research were conducted based on the relationship between social capital and performance (Bruderl \& Preisendorfer, 1998; Burt, 1997; Coleman, 1988; Pil \& Leana, 2009; Sagas \& Cunningham, 2005; sujchaphong, 2013). Employee behavior can improve through social capital by increasing the willingness to share knowledge among employees (Chisholm \& Nielsen, 2009; sujchaphong, 2013). Pakorn Sujchaphong(2013) done an emperical research about individual human capital and performance in thailand. Felício, Couto, \& Caiado (2014) done research regurding interrelationships between human capital and social capital in small and medium sized firms: the effect of age and sector of activity done study in Portugal. Batia Ben Hador (2016) done research, How intra-organizational social capital influences employee performance done in Israel. Most research has been developed and tested in the US and few research are tested in the Asian countries, such as Thailand, Israel, (Hofstede, 1983; Wright et al., 1995b; Pil \& Leana, 2009; Hanges, Javidan, Dorfman, \& Gupta, 2004).

\section{Research Problem}

The literatures and Previous studies were not providing enough evidence about how human capital and social capital effect to performance of the employee. Above studies focus on defining the human capital and Social Capital and investigating these variables as individual level with the various factors and measuring human capital in the organization ,as a concept Human capital management ,Human capital Management policies and procedures. There were few studies that evaluate the human capital and social capital effect to organization performance (Felício, Couto, \& Caiado, 2014), how the intra organization social capital influence to employee performance (Handor, 2016).

Even though there were variety of studies based on these variables, there was hidden area of studies that give evidence focus on the Human capital, social capital effect for employee performance. Human capital includes knowledge, skill, and abilities of people and when they leave the organization these specialties also leave the organization because these Specialties are bounded to employee. These some specialties are create through organization by investing on the employee. But some are not like that, it earn by employees by their own self and gradually year by year it develop by them. Social Capital is earn and develop by employees them self. Social capital include Knowledge gaining from network of relationship (Armstrong, 2006), status, mutual objective (Handor, 2016). Employee performance mean how well they do their jobs compared with a set of standards determined by the employer. To perform a job well employee need various skill, Knowledge, abilities, with that mutual objectives, trust, respect and appreciation sharing of information is needed. Using one specialty employee cannot perform well. Both Social capital and Human Capital factors are important to perform employee well in their job. Considering the Sri Lankan Context planned to do the study selecting small scale enterprises in 
Sri Lanka, under the problem statement of "Do Human Capital and Social Capital impact on employee Performance?"

\section{Objectives of the Study}

i. To assess the impact of human capital on employee performance

ii. To assess the impact of social capital on employee performance

iii. To identify what extent these dimension are impacting on employee performance and identify the thoughts of employees regarding human capital and social capital

\section{Literature Review}

\section{Human Capital}

Adam Smith (1776) was the first classical economist to include human capital in his definition of capital. According to the Smith (1776) Human capital mean acquired and useful talents, because human skills increase wealth of society as well as for the individual .Knowledge-based economies create human capital as one of the leading public policy. According to Coff (2002) human capital is Knowledge is that embodied within people. According to Hitt, Bierman, Uhlenbruck, and Shimizu (2006) defined human capital is the thing that employee added capability and experience so human capital include education, experience, skills, characteristics of employees. Human capital is aggregation of investments in activities, such as education, health, onthe-job training and migration that increase the each an individual productivity. Human capital is combination of the essential abilities and the knowledge and skills that people acquire and develop throughout their lifetime (Laroche,1998). Organizational human capital is the accumulated value of individual human capital (Ployhart \& Moliterno, 2011; Sujchaphong, 2013). Human capital is a source of sustainable competitive advantage of the organization because that produced valued, rare, and unique and nonsubstitutable. There is a separation between general human capital and specific human capital (McMahan et. al, 1999; wright \& McMahan, 1992; wright et. al, 1994). Context generic Human capital used for different tasks in the organization, while context specific human capital used only for specific task (ployhart \& Moliterno,2011; Sujchaphong, 2013).Context generic human capital more unchanging across time and situation and Context specific human capital is changing at time and situation(Jensen,1998; Kanfer,1990; McMahan et. al, 1999; wright \& McMahan ,1992).Context generic human capital contain 3 Component ,Knowledge, Skill, ability (Sujchaphong, 2013).

Knowledge defined as evidence whose validity has been recognized through tests of proof (Liebeskind, 1996; Sujchaphong, 2013). Knowledge can be define as understanding of standard, evidences and process (ployhart \& Moliterno, 2011; Sujchaphong, 2013). According to Spencer (1993) Skill mean the capability to complete certain physical or mental task. Ability mean economic term is average rate of return of whole investment costs in human capital (Becker, 1964; Sujchaphong, 2013). Ability represent Individual differences in Speed, efficiency, capability of the mental operation (Jensen, 1998; Sujchaphong, 2013). 


\section{Social Capital}

To success human capital, social capital is definitely need to apply, it mean social capital generate more opportunities to use human capital in a workplace. Social capital mean happens in the relations among people and it created quality among people and quality of the individual is human capital (Burt, 1997; Sujchaphong, 2013). The concept of social capital has been defined by According to Colaman (1995) Social Capital mean a function, with different entities having two characteristic of common.it consist of various aspect in social structure and if helps individuals several action who are within the structure.

But according to Putnam (1996) Social capital categories in to networks, norms, trust, that allow participant to perform combine shared objectives more effectively. Social capital mean a realworld links between groups or individuals, networks of friends, family networks, networks of former colleagues, and so on. Our shared norms, values and understandings are less actual than our social network. Social capital like human capital or financial capital, it is productive, create value, get things done, achieve goals, fulfill missions in life, and make contributions to the world. Scientifically proven that benefits of relationships for people, groups, and firms in the world of business. Many resources available to us in and throughout personal and business networks. Individuals who build, use social capital get better jobs, better pay, faster promotions, and are more influential and effective, compared with peers who are unable tap the power of social capital (Baker, 1962, 1964).
Social capital can categorized in to 3 level, Such as personal Social capital, Intra organizational social capital and external social capital (Hador, 2016) Individual Social Capital were fixed of resources that individual brought to perform their task through their own personal relations (Lazega et al., 2006; Hador, 2016) and also it was Individual's profit from the individual's placing in social network (Woolcock, 1998; Mouw, 2003; Yang et al., 2011; Hador, 2016). External social interaction mean collaboration of people within the organization, such as CEO and top management, competitor, investors , clients, suppliers and other third party (Yu and Junshu,2013; Carmeli, 2007; Kapucu and Demiroz, 2015).Intra organitional social capital consequent from connection within and between formal and formal groups in organizations from the level of work team in the whole organization. (Leana and Van Buren, 1999; Lee et al., 2016; Hador, 2016). Intra-organizational social capital (Adler and Kwon, 2002; Hador, 2016) is an intangible asset it create through the connection between people (Bourdieu, 1983; Hador, 2016). It is covered the objective and collaboration (Fukuyama, 1995; Hador, 2016) trust, norms, and organizational networks (Putnam, 1993: Hador, 2016). social capital was found to enhance the employees daily work life (Mahajan \& Benson, 2013; Hador, 2016). There were several benefit through intra organizational social capital. Such as reducing turn over,decrease employee absent sum, increase employee satisfaction, create helpful environment to share knowledge and information exchange (Tansley and Newell,2007; Van Emmerik and Euwema, 2008; Hador, 2016).Intra organization Social 
capital includes mutual objectives (Leana and Van Buren, 1999 Hador, 2016), trust (Yen et al. Hador, 2016) status (Ring, 1996 ;Hador, 2016), sharing of information and knowledge (Nahapiet and Ghoshal, 1998 Hador, 2016).

\section{Employee Performance}

Through result oriented employees find the easiest approach to achieve target without thinking the other important behavior (Murphy \& Deshon, 2000; weerakkody \& Jayaratna , 2016). Performance contained behavior that employee truly involve that can be observed, it highly depend on perception, value attitude. There were so many variable that effect to employee performance (Samad, 2011; Weerakkody \& Jayaratna , 2016). According to Ravai (2004) performance is the overall outcome or success of a person during certain periods of duty compared to the standard of the work, the targets or criteria that have been determined in advance and have been agreed. According to him 'performance influenced by various characteristics of each individual. Such as skills, abilities and individual traits, now a day's company require high performers to achieve competitive advantage. An individual cannot perform job successfully without having proper knowledge about job (Jensen, 1998; Sujchaphong, 2013). According to Commerce Dictionary.com employee performance mean degree to which a job is complete well or badly and also how glowing the job completed according to standard and procedure. According to Commerce Dictionary.com employee performance mean degree to which a job is complete well or badly and also how glowing the job completed according to standard and procedure. Employee performance mean purpose of individual capability, skill and effort in situation (Lawler, 1964, Prasanga \& Gamage, 2012;weerakkody \& Jayaratna , 2016). When organization want employees for the workplace, leader should guarantee that employees are motivated and committed, can maximize their performance in their different roles (Armstrong, 2006). Delivering feedback about individual performance increase the future performance of that person. Knowledge about how work done, appreciation of person past success provide support for future accomplishment.

Trough the development plans provide information on what skill need for the near future. Knowledge of oraganization current and future talent is needed to decide what type of skill need to aquire within the oraganization (Aguinis, 2013). According to Hador (2016) Social capital influence employee performance by mediation of vigor. There are several dimension to measure job performance task, traits, behavior, result (Opatha, 2009) cited in (Jayarathna \& Weerakkody, 2014)and (Sujchaphong, 2013). Task mean a piese of work tobe done or undertaken accorging to business dictionary.Trait mean specific characteristic or qualties of employee use in the performing job.traits can be measured. Behaviour mean the methods the employee perform in the relation to the job, it include certain activities carried out by employee. Result mean the outcome of the job (Opatha, 2009). 


\section{Conceptual Framework}

Considering previous literature, researcher proposal a frame work illustrates the effect of Human Capital and Social capital to employee performance.

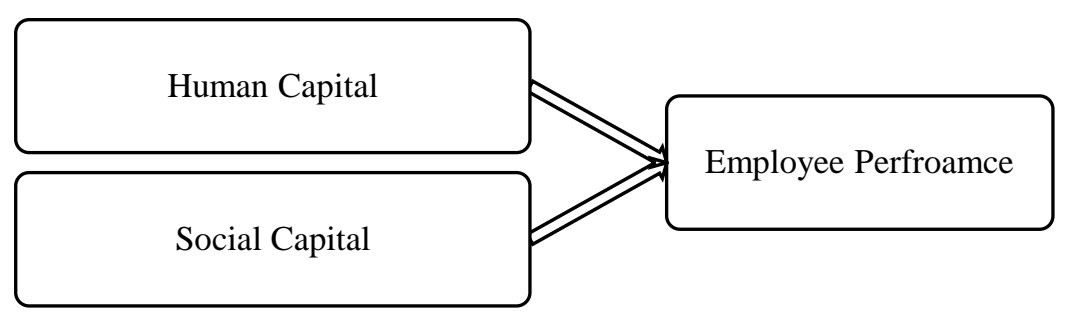

Figure 01: Conceptual Framework of the Study

Source: Authors, 2018

With Support of the above literature, Following hypotheses are tested in the study.

$\mathbf{H}_{1}$ : There is a significant impact of human capital on employee performance.

$\mathbf{H}_{2}$ : There is a significant impact of social capital on employee performance.

\section{Methodology}

This study was quantitative study and explanatory study where the hypotheses were develop to forecast the employee performance. This study purely based on Primary Data. Unit of analysis for this study was individual level .Data collect through standardized questionnaire and this was cross sectional study. Researcher interference was minimum in this study. As the total No of respondent in the population is known, this study use simple random sampling technique to collect data. Five Point Likert scale use to measure the responses to the questionnaire. The population for the current study is approximately 3000 employees. Worked in the small scale
Industrial enterprises in western province, Sri Lanka. But this exclude who are the employees in Construction and Agricultural sector Industry companies. Small scale organization define between $10 \quad-50$ employees working enterprises(world trade report ,2016) This research study concerned population as approximately 3000 employees work in small scale industrial enterprises sector that excluding construction and agricultural small Sector employees, in western province in Sri Lanka. Sample was selected as $10 \%$ from the Population and it were 316 employees in the small scale industrial enterprises in western province, Sri Lanka. Data were collect through 316 employee's small scale industrial enterprises in western province. Small scale industrial enterprises had been identified as an important strategic Sector for promoting growth and social development of Sri Lanka and majority of small scale industrial enterprises concentrated in western province based on Industrial census, 2007. 


\section{Analysis and Results}

The internal Consistency of the data were assured by testing the reliability using Cronbach's alpha test and validity check using KMO and Bartlett's Test. Cronbach's alpha value of the Human Capital, Social Capital and employee performance was $0.844,0.820$, and 0.785 , which propose that there were higher internal consistency reliability of each instrument. Validity of Human capital, Social Capital, Employee performance $0.889,0.770,0.878$.

\section{Hypothesis One}

There are two independent variables where individually test the direct impact on the dependent variable. According to that Human Capital Pearson Correlation Coefficient is 0.659 . It shows there is a strong positive relationship among human Capital and employee performance. Further, correlation coefficient is significant at the 0.01 level as sig (2-tailed); which is 0.000 . And also Simple regression equation is Employee performance $=1.754+0.492$ Human Capital , R Square is 0.434 it indicate that $43.4 \%$ variation of employee performance is explained from the variation of human capital. In other word, there is positive impact of human capital on employee performance is just $43.4 \%$. While remaining unexplained $56.6 \%$ were due to factors other than human capital. Hence Based on the test result $\mathrm{H} 1$ can be accepted and it can be statistically concluded that there is a significant impact of Human Capital on employee performance.

Table 01: The impact of Human Capital on Employee Performance

\begin{tabular}{|c|c|c|c|c|c|c|c|c|}
\hline$\frac{0}{\frac{0}{a}}$ & $\begin{array}{l}\bar{d} \\
\text { ¿ }\end{array}$ & 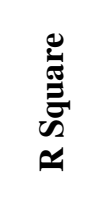 & 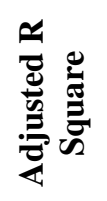 & : & 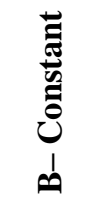 & 竺 & 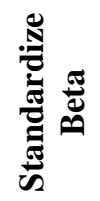 & 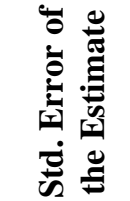 \\
\hline 壳芯 & Linear & 0.434 & 0.433 & 0.000 & 1.754 & 0.492 & 0.659 & 0.23696 \\
\hline
\end{tabular}

Source: Survey Data, 2018

\section{Hypothesis Two}

Social Capital Pearson Correlation Coefficient is 0.576 . It shows there is a moderate positive relationship among social Capital and employee performance. Further, correlation coefficient is significant at the 0.01 level as sig (2-tailed); which is 0.000 . And also Simple regression equation is
Employee performance $=2.415+0.308$ Social Capital , R square value is 0.332 .it indicate that $33.2 \%$ variation of employee performance are explained from the variation from Social capital. In other word, there is impact of Social capital on employee performance is just $33.2 \%$ while remaining unexplained 
$66.8 \%$ were due to factors other than Social capital. Hence, Based on the test result $\mathrm{H}_{2}$ can be accepted and it can be statistically concluded that there is a significant Positive impact of Social Capital on employee performance.

Table 02: The impact of Social Capital on Employee Performance

\begin{tabular}{|c|c|c|c|c|c|c|c|c|}
\hline$\frac{\frac{0}{a}}{\frac{\pi}{\pi}}$ & $\frac{\bar{d}}{\delta}$ & 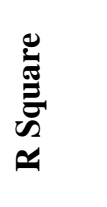 & 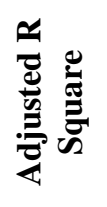 & : & 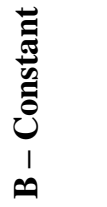 & 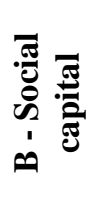 & 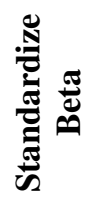 & 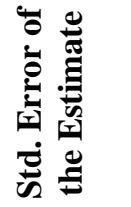 \\
\hline $\begin{array}{c}\text { Social } \\
\text { Capital }\end{array}$ & Linear & 0.332 & 0.330 & 0.000 & 2.415 & 0.308 & 0.576 & 0.25756 \\
\hline
\end{tabular}

Source: Survey Data, 2018

\section{Multiple Regression Analysis}

Multiple regression equation is ( $\mathrm{Y}=$ $\left.1.569+0.366 \mathrm{X}_{1}+0.162 \mathrm{X}_{2}\right)$, Employee performance $=1.569+0.366$ Human capital +0.162 Social Capital. Adjusted R square value is 0.494 .it indicate that $49.4 \%$ variation of employee performance are explained from the variation from both Human capital and Social capital. In other word, there is impact of both human capital and Social capital on employee performance is just $49.4 \%$ while remaining unexplained $50.6 \%$ were due to factors other than Human capital and Social capital.

\section{Discussion of Findings}

Human Capital (Knowledge, Skill, Attitude) be most important to perform the job well, without these employee cannot perform job well, therefore human capital has directly effect to employee performance in the organization. This study highlight human capital as an alternative of human resource practices. One objective of the study is to examine the impact of human capital on employee performance in small scale industrial enterprises in western province. The result of this study investigate the relationship between human capital and employee performance. Based on the outcome from Pearson correlation analysis, it indicated there was a significant positive impact of human capital on employee performance at the $99 \%$ confidence level. Researcher was able to find human capital has a positive significant impact on employee performance. Social Capital (Mutual objectives, trust, respect and appreciation sharing of information) be and also most important to perform the job well, because collaboration between employees improve day to day work life of employee it impact to employee outcome also. Therefore Social capital has directly effect to employee performance in the organization. Objective two of the study is to examine the impact of social capital on employee performance of individual employees in small scale industrial enterprises in western province Based on the outcome from Pearson correlation analysis, it indicated there was a moderate positive impact of social capital on employee performance at the $99 \%$ confidence level. As result of this study researcher 
was identify there is a positive significant impact of both human Capital and social capital on employee performance $49.4 \%$ according to multiple regression analysis.

\section{Limitations of the Study}

This research have several limitation. Regarding the population selected for the study is too contracted, because it only include industrial category in small enterprises sectors.it exclude the service sector and the trade sectors. And also sample get only from the western province, cannot spread to other province due to time limitation. However, if data can be collected throughout the country, result can be more generalize. Sometime other organization factor may be effect to the result of the research. Some employees and the organization have bound relationship so that correct result not be obtain. Some time employee might not be correctly answer because it take time for reading well and answering the questionnaire due to time limitation and the high work pressure. This study based on the personal view of respondent through questionnaire. Sometime became bias and ineffective due to respondent feeling will effect to the answer. This is a cross sectional study sometimes time differences will effect to the result validation.

\section{Directions for Future Studies}

For future researchers, this study suggest that studying human capital and social capital factors on employee performance, other scale enterprises such as medium and large scale organization. Since this study limited to cross sectional study, for future researcher could be done research as longitudinal design. In addition to that, could investigate by using other method such as interviews, focus group discussion and observation method. Finally further research can examine the interrelationship of both these variable how effect to employee performance.

\section{References}

Adler , P., \& Kwon, S.-W. (2002). Social Capital: Prospects for a New Concept. The Academy of Management Review, 17-40.

Diebolt , C., \& Haupe, M. (2014). Human Capital. (C. Diebolt, \& M. Haupert, Eds.) Handbook of Cliometrics

Jayarathna, S., \& Weerakkody, W. (2014). Impact Of Administrative Practices On Job Performance With Reference To Public Banks In Sri Lanka. International journal of scientific \& technology research, volume 3.

Lepak , D., \& Snell, S. (1999). The Human Resource Architecture,toward a theory of human capital Allocation and Development. Acadamy of Management Review.

tantardini, M., \& Kroll, A. (n.d.). The Role of Organizational Social Capital in Performance Management. Public Performance \&Management Review.

Torrington, D., Hall, L., \& Taylor, S. (2005). Human Resource Management (sixth edition ed.). 
Adhikari, D. R. (2010). Human resource development (HRD) for performance management: The case of. International Journal of Productivity and Performance Management, Volume Four, 306-324.

Aguinis, H. (2013). Performance Management. Edinburgh Business School HeriotWatt University.

Armstrong, M. (2006). A Handbook of Human Resource Management Practise (Tenth Edition ed.).

Boxall, P., Purcell, J., \& Wright, P. (Eds.). (2007). The Oxford Handbook of Human Resource Management . New York: Oxford University Press.

Chalofsky, N. F. (2014). Handbook of Human Resource Development . (N. Chalofsky, T. Rocco, \& M. L. Morris, Eds.) John Wiley \& Sons .

Channar, Z., Talreja, S., \& Bai, M. (2015). Impact of Human Capital Variables on the. Pakistan Journal of Commerce and Social Sciences, Ninth Volume, 228-240.

Chamanifard , R., Nikpour , A., \& chamanifard, s. (2015). The Effect of Social Capital on Organizational Performance:The Mediating Role of Employee's Job Satisfaction. International Review of Management and Business Research, Volume Four.

Coleman, J. S. (1988). Social Capital in the Creation of Human Capital. The American Journal of Sociology, , 95-120.

Dessler, G. (2014). Fundamentals of Human Resource Management (Third Edition ed.)

Felício, J., Couto, E., \& Caiado, J. (n.d.). Interrelationships between human capital and social capital in small and medium sized firms: The effect of age and sector of activity. 46.

Hador, B. B. (2016). How intra-organizational social capital influences employee performance. Journal of Management Development, 1119-1133.

Hador, B. B. (2017). Three levels of organizational social capital and their connection to performance. Journal of Management Development, 348-360.

J. Augusto Felício, E. C. (2014). Human capital, social capital and organizational performance. Management Decision, 52, 350-364.

Laroche, M., \& Mérette,, M. (n.d.). On the Concept and Dimensions of Human Capital in a Knowledge-Based Economy Context. 98-01.

Leana ,, C., \& Buren, H. (1999). Organizational Social Capital and Employment Practices. The Academy of Management Review, 538-555.

Mulgan, G., Matarasso, F., \& Madanipour, A. (2005, April). Physical Capital:How great places boost public value. 72 . 
Pawirosumarto, S., Katijan Sarjana, P., \& Muchtar, M. (2017). Factors affecting employee performance. International Journal of Law and Management, 602614.

Report, C. T. (2017). Human capital theory :assessing the evidence for the value and importance of people to organisational success.

Rompho,, B., \& Siengthai, S. (2012). Integrated performance measurement system for firm's human capital building. Journal of Intellectual Capital.

Sekaran, U. (2010). Research Methods for Business - A skill Building Approach (Fourth Edition ed.).

Sujchaphong, p. (2013). Individual human capital and performance: an empirical study in thailand.

Torrington, D., Hall, L., Taylor, S., \& Atkinson, C. (2014). Human Resource Management (Ninth edition ed.).

Weerakkody, W., \& Jayarathna, D. (2016). Impact of Decision Making, Reward Management on Job Performance: Mediation ofjob Satisfaction: A Case of a Private Banks in Sri lanaka 